\title{
A quantitative RT-PCR study of the mRNA expression profile of the IGF axis during mammary gland development
}

\author{
M Boutinaud, J H Shand, M A Park, K Phillips, J Beattie, D J Flint and G J Allan \\ Molecular Recognition Group, Hannah Research Institute, Ayr KA6 5HL, UK
}

(Requests for offprints should be addressed to M Boutinaud who is now at UMR Production de lait, INRA, 35590 Saint-Gilles, France; Email: boutinau@st-gilles.rennes.inra.fr)

\begin{abstract}
We have used quantitative RT-PCR to analyse the mRNA expression profile of the major components of the IGF axis in different stages of murine mammary gland development, including late pregnancy, lactation and involution. We have shown that all the genes studied, IGF-I, IGF-II, IGF receptor (IGFR) and IGF-binding protein (IGFBP)-1 to -6, were expressed in every stage, albeit at greatly differing levels and displaying unique expression profiles between developmental stages. IGF-I was always expressed at significantly higher levels than either IGF-II or IGFR. This suggests that IGF-I may be the more important IGF during mammary morphogenesis. Overall, IGFBP-3 demonstrated the highest level of expression of any of the IGFBP genes throughout all the developmental stages studied. However, within developmental stages, by far the highest level of expression of any of the IGFBPs was that of IGFBP-5 at day 2 of involution; this was almost an order of magnitude higher than any of the other IGFBP levels recorded. This corroborated our previous findings that the levels of IGFBP-5 protein are highly elevated in the involuting mammary gland, and demonstrated that this up-regulation of IGFBP-5 operates at the level of transcriptional control or message stability. Comparison of the expression profile for these different genes would strongly suggest that they are likely to have differential functions throughout mammary gland development, and also highlights potential interactions and co-regulation between different members of this axis. In addition, our results have identified some similarities and differences in the expression of IGFBPs between the mouse mammary epithelial cell line, $\mathrm{HC11}$, and the normal mammary gland which are worthy of study, most notably the differential regulation of IGFBP-2 and the site of expression of IGFBP-4 and -6. Overall, this study has demonstrated the importance and complexity of the IGF axis during mammary gland development and provides a valuable resource for future research in this area.
\end{abstract}

Journal of Molecular Endocrinology (2004) 33, 195-207

\section{Introduction}

The insulin-like growth factor (IGF) signalling pathway consists of two growth factors, IGF-I and IGF-II, a cell surface receptor, IGFR, and six high-affinity IGF-binding proteins, IGFBP-1 to -6 (for review see Hwa et al. 1999). The IGF axis plays an important role in the normal growth and development of a wide variety of tissues. There is strong evidence that the IGF axis plays an important role in the various stages of mammary gland development, including pre- and postpubertal growth and the extensive developmental changes which occur during pregnancy, lactation and involution. Both in vitro and in vivo studies have demonstrated a mitogenic role for IGFs on mammary cells; in vitro it has been shown that IGF-I and -II can stimulate the proliferation of mammary cells (Imagawa et al. 1986, Strange et al. 2002, Stull et al. 2002), and in vivo IGFs have been shown to be able to promote mammary ductal growth during mammogenesis (Richert \& Wood 1999, Ruan \& Kleinberg 1999). Furthermore, IGF-II was proposed to be a major mitogen for ductal epithelium during pregnancy, as its expression pattern correlated with highly proliferating cells (Richert \& Wood 1999). Although, IGF-I or -II injections were unable to prevent the inhibition 
of lactation that occurs in prolactin- and growth hormone (GH)-deficient rats (Travers et al. 1996), it has been suggested that GH may act through local production of IGFs, and the ability of GH to rescue mammary development in mice with a single allele of the prolactin receptor was shown to be partly mediated by the IGF axis (Allan et al. 2002). Indeed, IGF-I may act on mammary cells in an autocrine or paracrine manner since IGF-I secretion has been demonstrated in the mammary gland (Yee et al. 1989). IGFs have also been shown to be important survival factors for mammary cells in vitro (Geier et al. 1992). Involution of the mammary gland is characterised by the apoptosis of large numbers of mammary epithelial cells, and support for IGFs as survival factors for mammary epithelium in vivo comes from the finding that there is a delay in mammary involution when IGF-I or -II are over-expressed in transgenic mice (Hadsell et al. 1996, Neuenschwander et al. 1996, Moorehead et al. 2001).

In turn, the effects of the IGFs are modulated by the IGFBPs, which have also been shown to have numerous effects in the developing mammary gland (for review see Flint et al. 2000). In vitro experiments with mammary epithelial cell cultures have shown that IGF-I or -II treatment can stimulate IGFBP expression (McGrath et al. 1991, Fielder et al. 1992, Skaar \& Baumrucker 1993), while other studies have shown that IGFBP-1, -2, -3 and -5 are capable of suppressing IGF-Imediated survival of these cells (Yee 1994, Purup et al. 2000, Strange et al. 2002, Marshman et al. 2003). In addition, it has been shown that IGFBP-3 and -5 can inhibit growth and promote apoptosis of human breast cancer cell lines in an IGFindependent manner (Oh et al. 1993, Rajah et al. 1997, Butt et al. 2003), with the latter binding protein employing an intracellular mechanism of action. We have previously demonstrated that the expression of IGFBP-5 protein is highly up-regulated in vivo during involution of the mammary gland (Tonner et al. 1995, 1997) and have proposed that IGFBP-5 might serve to induce apoptosis of mammary epithelial cells by inhibiting the cell survival actions of IGFs (Tonner et al. 2000). More recently, we have shown a causal link between IGFBP-5 and cell death in the mammary gland by either specifically over-expressing the binding protein in the mammary glands of lactating transgenic mice (Tonner et al. 2002) or injecting recombinant IGFBP-5 protein into the mammary glands of lactating wild-type mice (Allan et al. 2002). This is potentially a very significant finding when one considers that several anti-proliferative agents used in breast cancer clinical trials have also been shown to up-regulate IGFBP-5 in a human breast cancer line (Huynh et al. 1996, Rozen et al. 1997).

The power of quantitative RT-PCR is reflected in the increasing literature based on this technology. This includes the monitoring of PCR amplifications in real time, combined with extremely high levels of sensitivity and accuracy. Perhaps the most important application of this is that appropriate software then allows the accurate quantification of a target mRNA in biological samples at different times of development or following different treatments. In this study, we set out to use this technology to establish the mRNA expression profiles of the various components of the IGF axis during murine mammary gland development. We believed that this would provide an important base for future studies aimed at elucidating the functionality of the IGF axis in mammary gland development and our choice of the murine mammary gland was in recognition of the obvious potential for transgenic technology in this area. Furthermore, we have carried out a parallel in vitro study looking for similarities and differences in IGF axis mRNA expression profiles in a mouse mammary epithelial cell line, HC11. These cells undergo proliferation and differentiation similar to that observed in vivo during mammary gland development and can be induced to differentiate and express $\beta$-casein by treatment with dexamethasone, insulin and prolactin (DIP) (Ball et al. 1988a,b). We recently demonstrated that DIP treatment of HC11 cells is associated with a change in the levels of expression of IGFBP-2- and -5-secreted protein (Phillips et al. 2003).

\section{Materials and methods}

\section{Cell culture}

The mouse mammary epithelial cell line, HC11, was a kind gift from Dr Bruce Whitelaw, Roslin Institute, Edinburgh, UK. HC11 cells were grown to confluence in 12-well culture dishes (over a period of 2-3 days) in $1 \mathrm{ml}$ complete medium (Dulbecco's minimum Eagles's medium (DMEM), 
$10 \%$ fetal calf serum, 100 units/ml PenStrep (GIBCO, Paisley, UK), $2 \mathrm{mM}$ glutamine, $1 \mathrm{mM}$ $\mathrm{Na}$ pyruvate, $5 \mu \mathrm{g} / \mathrm{ml}$ insulin and $10 \mathrm{ng} / \mathrm{ml}$ epidermal growth factor (EGF)). Insulin and EGF are required in culture medium to produce competent cultures, which are then able to respond to treatment with lactogenic hormones. After 2 days at confluence, competent cell cultures were induced to differentiate under serum-free conditions by treatment with DMEM containing $5 \mu \mathrm{g} / \mathrm{ml}$ insulin, $5 \mu \mathrm{g} / \mathrm{ml}$ prolactin and $1 \mu \mathrm{M}$ dexamethasone $(500 \mu \mathrm{l}$ per well; DIP). Incubations were continued for 2 days at which time cell monolayers were lysed for the analysis of mRNA profile via real-time PCR. Undifferentiated control HC11 cell cultures were obtained by culturing competent cells in DMEM in the absence of lactogenic hormones.

\section{Animals}

All animal studies were conducted under appropriate licence from the UK Home Office and after approval by local ethical review committees. The source of mammary tissues used for these studies was from $\mathrm{BA} \times \mathrm{C} 57 \mathrm{Bl} / 6$ strains of mice, and the developmental stages were as follows: late pregnant (18 days gestation; P18), lactating (day 1 and day 10 postpartum; L1 and L10 respectively) and involution ( 2 and 4 days after pup removal; I2 and I4 respectively). All animals were primiparous and litters were fixed at eight to minimise mouse-tomouse variation in suckling response. Animals were killed by cervical dislocation. Mammary glands were surgically removed from the mice and rapidly frozen in liquid nitrogen and stored at $-80{ }^{\circ} \mathrm{C}$ until use. The samples were then reduced to powder by pulverising the frozen tissue in liquid nitrogen with a mortar and pestle.

\section{Total RNA extraction}

Total RNA was extracted from the mammary gland samples and HC11 cells using TRIZOL reagent according to the manufacturer's protocol (Life Technologies, Paisley, Strathclyde, UK). Briefly, $100 \mathrm{mg}$ mammary tissue powder were homogenised in $1 \mathrm{ml}$ TRIZOL reagent at room temperature. For HC11 cells, $1 \mathrm{ml}$ TRIZOL was added after removal of growth medium, and the cells were harvested and homogenised by passing the solution through a pipette tip several times.
Chloroform $(0 \cdot 267 \mathrm{ml})$ was added to the homogenate and, after $2 \mathrm{~min}$ incubation at room temperature, the mixture was centrifuged at $12000 \mathrm{~g}$ for $15 \mathrm{~min}$ at $4{ }^{\circ} \mathrm{C}$. The aqueous supernatant containing total RNA was separated and $0.667 \mathrm{ml}$ isopropyl alcohol was then added for $10 \mathrm{~min}$ at $-20^{\circ} \mathrm{C}$ to precipitate the RNA. The RNA was pelleted by centrifugation $(12000 \boldsymbol{g}$ for $10 \mathrm{~min}$ at $4{ }^{\circ} \mathrm{C}$ ), rinsed with $70 \%$ ethanol and finally dissolved in sterile distilled water (Life Technologies). The amount of total RNA extracted from either mammary gland tissue or HC11 cells was measured by absorbance at $260 \mathrm{~nm}$.

\section{Reverse transcription}

A first strand cDNA synthesis kit (Roche Diagnostics, Lewes, E Sussex, UK) was used for cDNA synthesis according to the manufacturer's instructions. Total RNA $(2 \mu \mathrm{g})$ was incubated for $1 \mathrm{~h}$ at $42{ }^{\circ} \mathrm{C}$ with 15 units AMV reverse transcriptase, $1 \cdot 6 \mu \mathrm{g}$ oligo $(\mathrm{dT})_{15}$ primer, RNAse inhibitor at 2.5 units/ $\mu$, deoxynucleotide mix at $1 \mathrm{mM}$ and $1 \times$ reverse transcription buffer $(10 \mathrm{mM}$ Tris $\mathrm{HCl}$ $(\mathrm{pH} 8.3)$ and $50 \mathrm{mM} \mathrm{KCl}$ ) and $5 \mathrm{mM} \mathrm{MgCl}_{2}$ in a total volume of $20 \mu \mathrm{l}$. After the reaction was complete, the mixture was heated to $95{ }^{\circ} \mathrm{C}$ for 5 min to inactivate the AMV reverse transcriptase and chilled at $4{ }^{\circ} \mathrm{C}$.

\section{Primer design}

Gene sequences for primer design were obtained from the National Center for Biotechnology Information's GeneBank. Primer pairs for IGFBP-1 to -6, IGF-I, IGF-II and IGFR were designed using either the programme Primer Design, part of the DNASTAR suite (DNASTAR Inc., Madison, WI, USA), or the proprietary software supplied with the LightCycler instrument (Roche Diagnostics) to give amplification products between 200 and $800 \mathrm{bp}$. The intron/exon structure of the cDNA was obtained by comparison with the mouse genomic sequence or by extrapolation with multi-alignment to the human genomic sequence. The two primers were chosen to bind to separated exons in order to avoid genomic DNA amplification. Forward and reverse primer sequence for each gene and their corresponding amplicon size are provided in Table 1. For reliable quantification of IGF axis genes, primer pairs were tested by LightCycler 


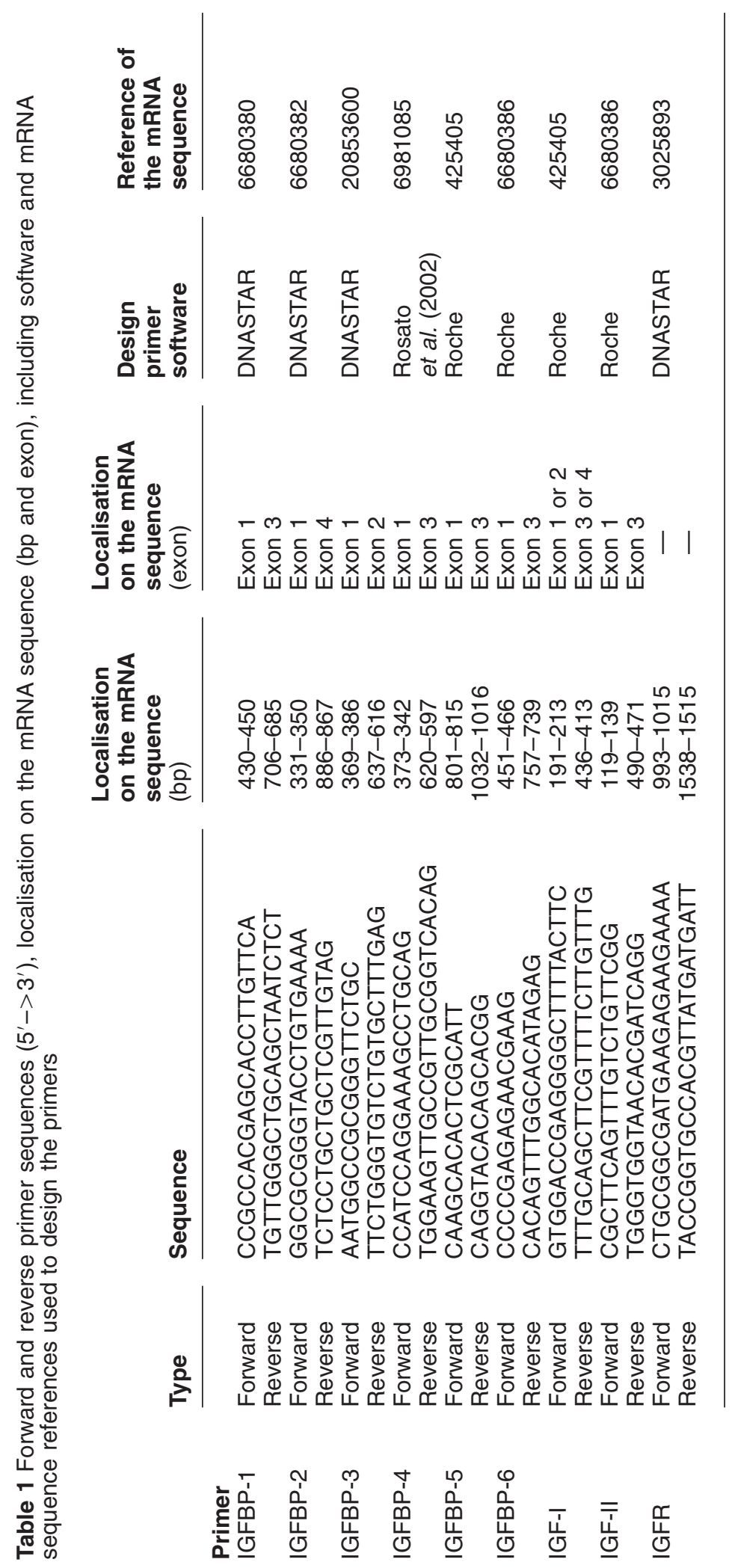


Table 2 Quantitative PCR conditions and RT-PCR product length for the LightCycler amplification of IGFBP and IGF CDNAs

\begin{tabular}{|c|c|c|c|c|}
\hline & $\begin{array}{l}\text { PCR product } \\
\text { length } \\
\text { (bp) }\end{array}$ & $\begin{array}{l}\text { Annealing } \\
\text { temperature } \\
\left({ }^{\circ} \mathrm{C}\right)\end{array}$ & $\begin{array}{l}\text { Elongation } \\
\text { time } \\
\text { (s) }\end{array}$ & $\begin{array}{l}\text { Fluorescence } \\
\text { acquisition } \\
\text { temperature } \\
\left({ }^{\circ} \mathrm{C}\right)\end{array}$ \\
\hline \multicolumn{5}{|l|}{ Primer pair } \\
\hline IGFBP-1 & 277 & 59 & 11 & 89 \\
\hline IGFBP-2 & 556 & 56 & 22 & 72 \\
\hline IGFBP-3 & 269 & 60 & 16 & 86 \\
\hline IGFBP-4 & 298 & 59 & 16 & 90 \\
\hline IGFBP-5 & 232 & 47 & 9 & 72 \\
\hline IGFBP-6 & 307 & 54 & 12 & 87 \\
\hline IGF-I & 246 & 60 & 20 & 86 \\
\hline IGF-II & 372 & 59 & 22 & 83 \\
\hline IGFR & 546 & 59 & 15 & 90 \\
\hline Cyclophilin & 165 & 58 & 7 & 81 \\
\hline
\end{tabular}

PGR. The primer pairs were chosen to give specific melting peaks following a melting curve analysis. To establish if amplification products were of the correct size, they were evaluated by $2 \%$ agarose gel electrophoresis, using $1 \times \mathrm{TBE}$ running buffer (0.09 M Tris-borate and 0.002 M EDTA, pH 7.8), staining with ethidium bromide and visualization by u.v. transillumination. The primer pair for cyclophilin, the housekeeping gene, had been previously designed by $\mathrm{C}$ Baly (Neurobiologie de l'olfaction et de la prise alimentaire, INRA, Jouy en Josas, France); the primer sequence for cyclophilin (forward primer 5'-CATCGTAAAGCATACAGGT CCTG-3'; reverse primer 5'-TCGATGGCTTCG ACAATGTT-3') gives an amplicon size of $165 \mathrm{bp}$.

\section{LightCycler PCR master mix}

The LightCycler PCR was performed using a FastStart DNA Master SYBR Green I Kit (Roche Diagnostics) according to the manufacturer's instructions. Briefly, a LightCycler master mix was prepared using $2 \mu \mathrm{l}$ LightCycler-FastStart DNA Master SYBR Green I with forward and reverse primers at a final concentration of $0.5 \mu \mathrm{M}$ each, and $\mathrm{MgCl}_{2}$ at $3 \mathrm{mM}$. A total volume of $18 \mu \mathrm{l}$ of LightCycler master mix was pipetted into LightCycler glass capillaries and $2 \mu \mathrm{l}$ of the cDNA product (diluted tenfold) was added as a PCR template. The capillaries were capped, placed in the LightCycler carousel and briefly centrifuged in a specific LightCycler centrifuge.

\section{Quantitative RT-PCR}

Quantitative RT-PCR was carried out on a LightCycler II instrument (Roche Diagnostics) and a standard LightCycler amplification cycle protocol was established for each gene. Thermal cycling was carried out as follows. The first segment of the amplification cycle consisted of a denaturation programme of $95^{\circ} \mathrm{C}$ for $10 \mathrm{~min}$. The second segment consisted of a four-step denaturation (15 s at $95^{\circ} \mathrm{C}$ ), primer annealing $(5 \mathrm{~s}$ at the specific annealing temperature for each gene; outlined in Table 2), elongation $\left(72{ }^{\circ} \mathrm{C}\right.$ for varying times depending on the gene; outlined in Table 2) and quantification programme repeated for 40 cycles. A single fluorescence acquisition point was specified for each gene at a particular temperature (see Table 2). The third segment consisted of a melting curve programme $\left(95^{\circ} \mathrm{C}\right.$ for $0 \mathrm{~s}, 57^{\circ} \mathrm{C}$ for $15 \mathrm{~s}$ and a linear temperature transition at $0.05{ }^{\circ} \mathrm{C} / \mathrm{s}$ from $57^{\circ} \mathrm{C}$ to $95^{\circ} \mathrm{C}$ with continuous fluorescence acquisition). The final segment consisted of a cooling programme to $40{ }^{\circ} \mathrm{C}$.

\section{Calibration curves}

LightCycler analysis software (Roche Diagnostics) allowed quantitative analysis of the PCR. A calibration curve for each IGFBP gene and for the housekeeping gene was generated from serial dilutions of a specific plasmid cDNA for each gene. The plasmid cDNA for the mouse IGFBPs (Schuller et al. 1994) and for the mouse cyclophilin (Hasel \& Sutcliffe 
1990) were kind gifts from V Cingel, (Laboratory of Pediatrics, Rotterdam, The Netherlands) and J G Sutcliffe (Scripps Research Institute, La Jolla, CA, USA) respectively. Recombinant plasmids were transformed into Escherichia coli JM109 competent cells and grown in LB medium containing tryptone $(10 \mathrm{~g} / \mathrm{l})$, yeast extract $(5 \mathrm{~g} / \mathrm{l})$ and $\mathrm{NaCl}(5 \mathrm{~g} / \mathrm{l})$, pH 7.5. Plasmid DNA was purified using a Qiagen Maxiprep kit (Qiagen, Crawley, E Sussex, UK) and quantified by its absorption at $260 \mathrm{~nm}$. From the calculated concentrations and knowing the molecular weight of each double-stranded recombinant DNA molecule, we were able to accurately plot the calibration points for serial dilutions of the plasmids ranging from $10^{8}$ down to $10^{2}$ molecules $/ 2 \mu \mathrm{l}$. The calibration curves were then constructed from plotting the crossing point against the log value of serially diluted standard plasmid cDNA. Once we had the calibration curves plotted, the number of molecules of each IGFBP RNA could be calculated after real-time amplification from the linear regression of the appropriate curve. However, for IGF-I, IGF-II and IGFR, we did not have appropriate plasmid cDNAs available. Therefore, for these three genes we adopted an alternative strategy, whereby we produced calibration curves using a single sample of RT product diluted several times $(1 / 1,1 / 10,1 / 20,1 / 100$ and $1 / 200)$ in order to obtain a linear regression slope. In order to compare the data between different runs, we calculated an approximate number of molecules for experimental RNAs using the slope for each gene and always the same Y-intercept $(42 \cdot 10)$. A non-template negative control was incorporated in all PGR runs.

\section{Statistical analysis}

Data were analysed by the methods of least squares ANOVA using the general linear model procedures in the epsilon Windows software (L Delaby, Uniti Mixte de Recherches sur la Production du Lait, INRA, France). Means were considered different if $P<0 \cdot 05$.

\section{Results}

\section{Confirmation of primer specificity}

The specificity of RT-PGRs was verified by checking that the PCR products were of the expected size by gel electrophoresis. The primer pair for each gene resulted in a single product with the desired length: IGFBP-1 $277 \mathrm{bp}$, IGFBP-2 556 bp, IGFBP-3 269 bp, IGFBP-4 298 bp, IGFBP-5 232 bp, IGFBP-6 307 bp, IGF-I 246 bp, IGF-II 372 bp, IGFR 546 bp and cyclophilin 165 bp (data not shown). In addition, a LightCycler melting curve analysis was performed which resulted in single product specific melting temperatures as follows: IGFBP- $190.5^{\circ} \mathrm{C}$, IGFBP-2 $91.0^{\circ} \mathrm{C}$, IGFBP-3 $91.4{ }^{\circ} \mathrm{C}$, IGFBP-4 $91.8^{\circ} \mathrm{C}$, IGFBP-5 $89 \cdot 7^{\circ} \mathrm{C}$, IGFBP-6 $90 \cdot 7^{\circ} \mathrm{C}$, IGF-I $88.7{ }^{\circ} \mathrm{C}$, IGF-II $92.3^{\circ} \mathrm{C}$, IGFR $87.1{ }^{\circ} \mathrm{C}$ and cyclophilin $84.7{ }^{\circ} \mathrm{C}$. Primer dimers were occasionally generated during real-time PCR amplification in the low concentration samples and in the template negative control. In this case, we chose a higher temperature of fluorescence acquisition than the classical value of $72{ }^{\circ} \mathrm{C}$ (Table 2).

\section{Calibration curves and quantification}

We constructed calibration curves for all of the IGFBPs and for cyclophilin mRNA using the recombinant plasmid as a standard. The resulting calibration curves demonstrated good efficiencies

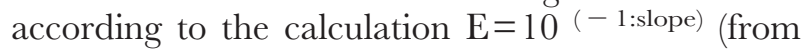
$1 \cdot 71$ to $1 \cdot 90)$. Samples were quantified in duplicate between different LightCycler runs, which demonstrated little variation between runs. We chose to use cyclophilin as a housekeeping gene, because the variation in its mRNA level between the mammary developmental stages was significantly lower than that for glyceraldehyde-3-phosphate dehydrogenase or $\beta$-actin (data not shown). Although we did obtain higher expression of cyclophilin mRNA at P18 and L1 compared with the other stages, we noted that this variation was always lower for cyclophilin than for the majority of the target genes (Figs 1 and 2).

\section{IGF axis mRNA profile in mammary gland developmental stages}

Using quantitative RT-PCR, transcripts for all of the IGF axis components were detected in all of the stages of mammary gland development that were studied (P18, L1, L10, I2 and I4; see Figs 1 and 2). It is important to note that for IGF-I, IGF-II and IGFR, quantification of mRNA levels could not be 

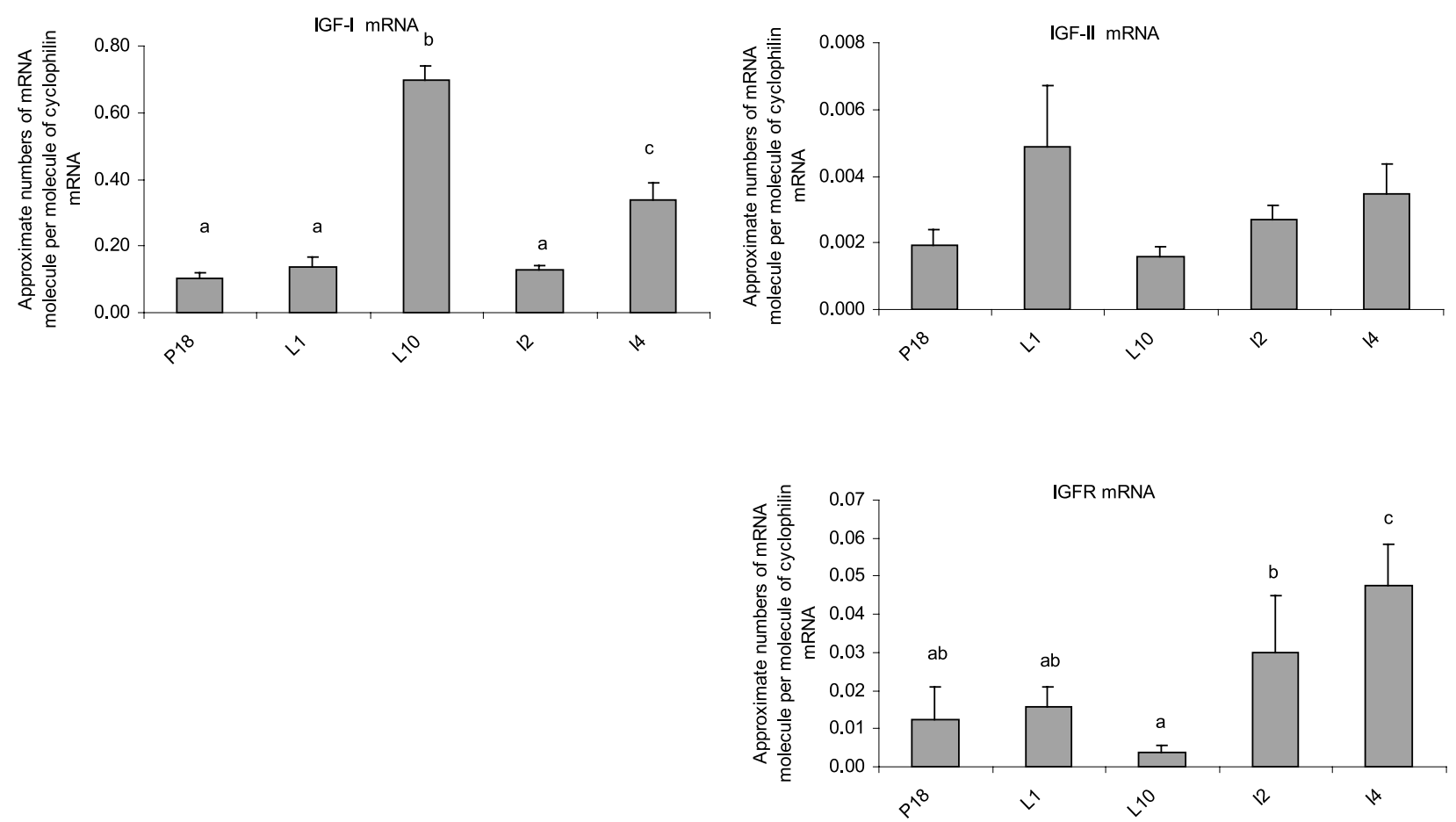

Figure 1 mRNA levels of IGF-I, IGF-II and IGFR in mouse mammary gland (expressed in approximate numbers of mRNA molecule per molecule of cyclophilin mRNA) $(n=17)$. Means with different superscript letters $(\mathrm{a}, \mathrm{b}$ and $\mathrm{c})$ differ significantly $(P<0.05)$.

determined in absolute terms, because for these genes we did not have an appropriate plasmid cDNA available in order to plot calibration curves. Nevertheless, we were able to make relative comparisons. We observed that IGF-I was expressed at much higher levels than either IGF-II or IGFR, and that its expression profile varied according to the development stage studied (Fig. 1). IGF-I mRNA levels peaked at L10, being sixfold higher $(P<0.001)$ at this stage compared with P18 and L1 and declined precipitously by I2, before increasing again threefold by $\mathrm{I} 4(P<0 \cdot 02)$. IGFR expression followed an almost reciprocal pattern, since it decreased between L1 and L10 and then increased dramatically on I2 and continued to do so by I4, reaching values more than eightfold higher than during lactation. The expression of IGF-II was approximately 100-fold lower than IGF-I, and no significant variation of IGF-II mRNA levels was observed between any of the developmental stages.

The mRNA profile of the IGFBPs varied according to the developmental stage studied (Fig. 2). However, unlike the IGFs and IGFR, calibration curves allowed the precise determination of the absolute number of IGFBP mRNA molecules. IGFBP-1 was expressed at extremely low levels at all stages, although there was a twofold increase in expression between $\mathrm{P} 18$ and L10 $(P<0.04)$ and a similar twofold decline between L10 and I4. IGFBP-2 showed a threefold increase at parturition, followed by a significant sixfold decline by L10 which persisted into involution. IGFBP-3 was expressed at very high levels at all stages and its expression was not significantly different at any stage examined. IGFBP-4 expression was also relatively high and showed only an involution-specific increase. IGFBP-5 was expressed at very low levels during late pregnancy and lactation but also showed a dramatic 54-fold increase by I2 $(P<0 \cdot 001)$, before declining again 2 -fold by I4 $(P<0 \cdot 02)$. Finally, IGFBP-6 was most highly expressed during pregnancy, declined fourfold during lactation before increasing threefold again between I 2 and I4. Figure 3 reiterates the same data, but allows direct comparison of the mRNA levels between the six IGFBPs at each developmental stage. This also clearly demonstrates 

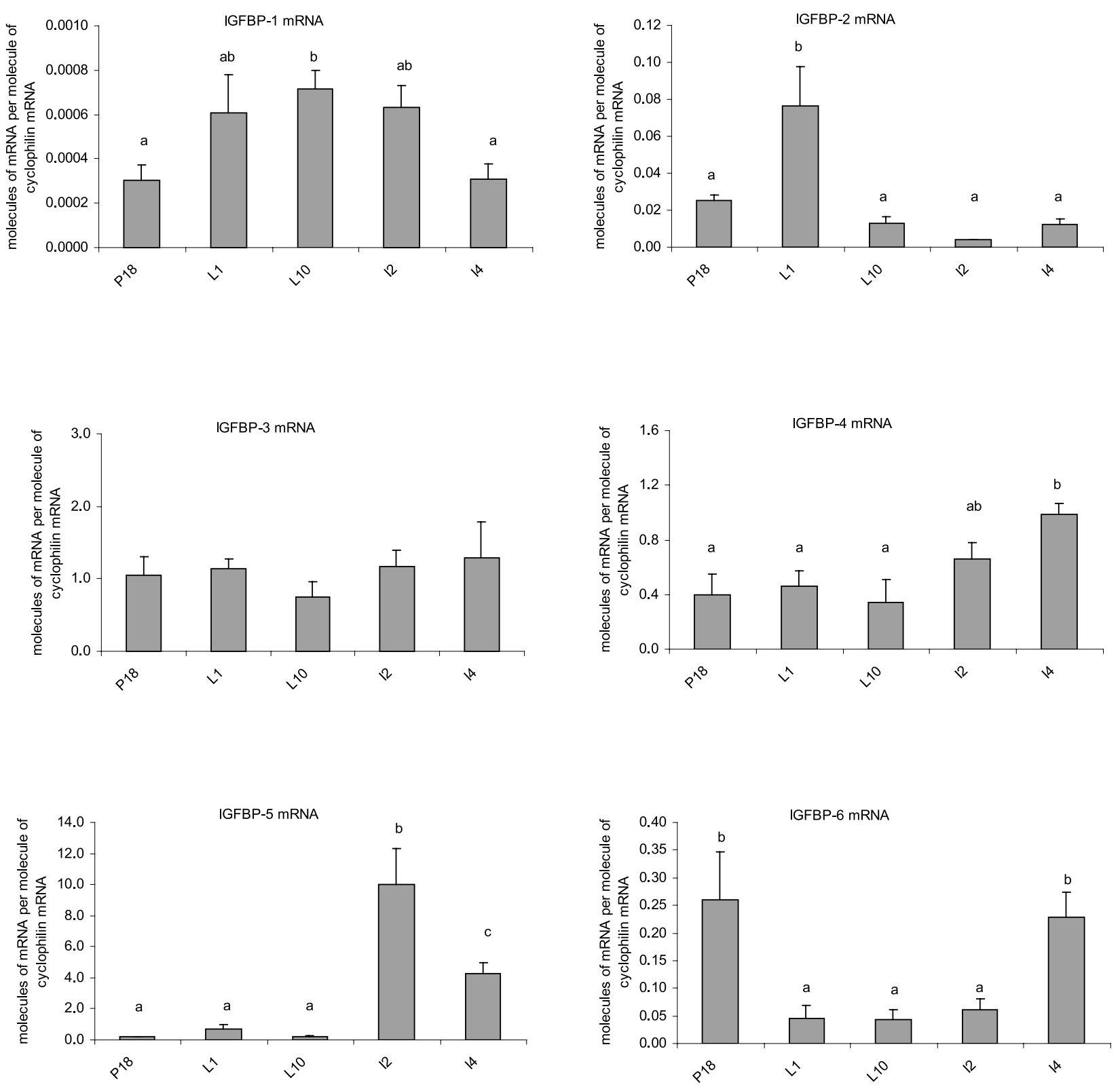

Figure 2 mRNA levels of IGFBP-1, $-2,-3,-4,-5$ and -6 in mouse mammary gland (expressed in approximate numbers of mRNA molecule per molecule of cyclophilin mRNA) $(n=17)$. Means with different superscript letters (a, $\mathrm{b}, \mathrm{c}$ and $\mathrm{ab})$ differ significantly $(P<0.05)$.

the significant overall increase in IGF-binding capacity at I2.

\section{IGF axis in HC11 cells}

Using quantitative RT-PCR, we were able to detect in vitro expression of IGFBP-1, -2, -3 and -5 , IGF-I and -II and IGFR mRNA in HCl1 cells, whereas no mRNA was detected for IGFBP-4 and -6 (Figs 4 and 5). IGFBP-3 and -5 were the most highly expressed binding proteins in $\mathrm{HCll}$ cells. However, levels of IGF-I and -II mRNA expression in HC11 cells were more than 100-fold lower than that in the mammary gland samples $(P<0 \cdot 001)$, whereas IGFR mRNA levels were more than 10-fold higher in HC11 cells than in vivo. DIP 


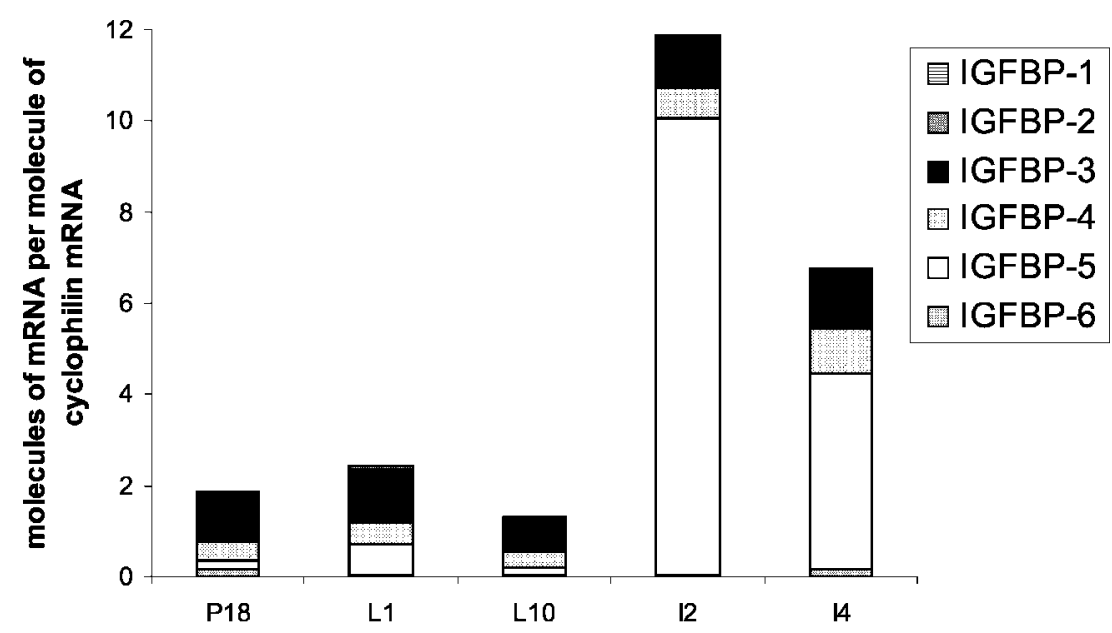

Figure 3 Comparison of the number of mRNA molecules per molecule of cyclophilin mRNA for all six IGFBPs in the different developmental stages of the mammary gland studied. In descending order, each bar displays the expression of IGFBP-1 through to -6. In some stages, the expression levels of IGFBP-1, -2 and -6 were too low to be represented.

treatment of HC-11 cells led to a decrease in IGFBP-2 and -3 and IGFR mRNA expression $(P<0 \cdot 05)$ and an increase in the expression of IGFBP-5 and IGF-II. DIP treatment had no significant effect on the expression of either IGFBP-1 or IGF-I mRNA.

\section{Discussion}

This study presents strong evidence that the entire IGF axis is expressed throughout mammary gland development, and is therefore likely to be central to morphogenetic events in the gland. Furthermore, our work describes complex temporal mRNA expression patterns between the various developmental stages studied, suggesting that the multiple components of the IGF axis may have distinct functions in the developing gland.

It is clear from our work that IGF-I mRNA is expressed at much higher levels than IGF-II in all of the mammary gland stages. This implies that IGF-I is the more important IGF with respect to gland development, which would concur with the proposal that circulating IGF-I is the principal IGF in the adult mouse. Furthermore, the expression profile of the two IGFs in the mammary gland is quite distinct, with IGF-I peaking at L10 and declining dramatically during early involution. This is the reciprocal of the changes seen in circulating concentrations of IGF-I, which are lowest during established lactation, reflecting the catabolic state in which these animals find themselves (Sorensen \&
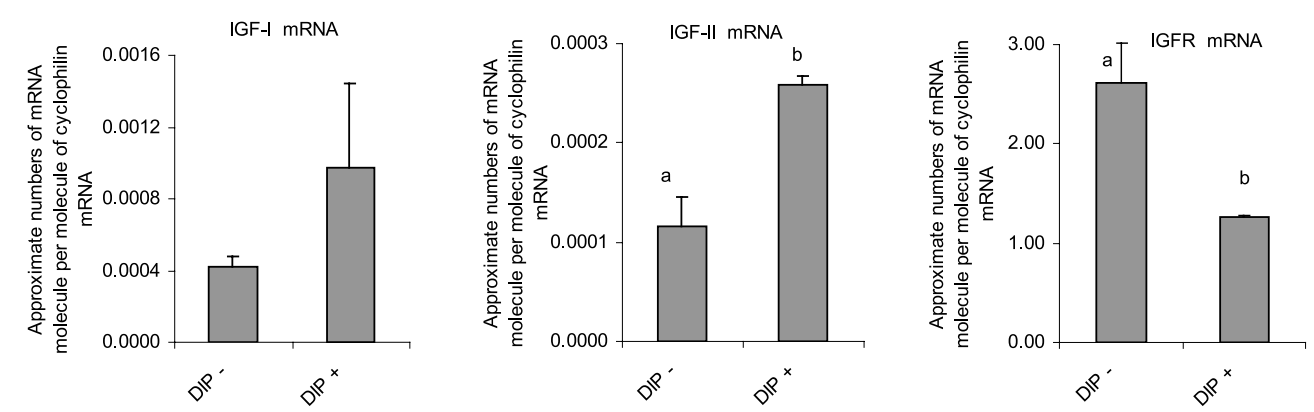

Figure 4 mRNA level of IGF-I, IGF-II and IGFR in DIP-treated (DIP+) and -untreated (DIP-) HC11 cells (expressed in numbers of mRNA molecules per molecule of cyclophilin mRNA $(n=6)$. Means with different superscript letters (a and b) differ significantly $(P<0.05)$. 

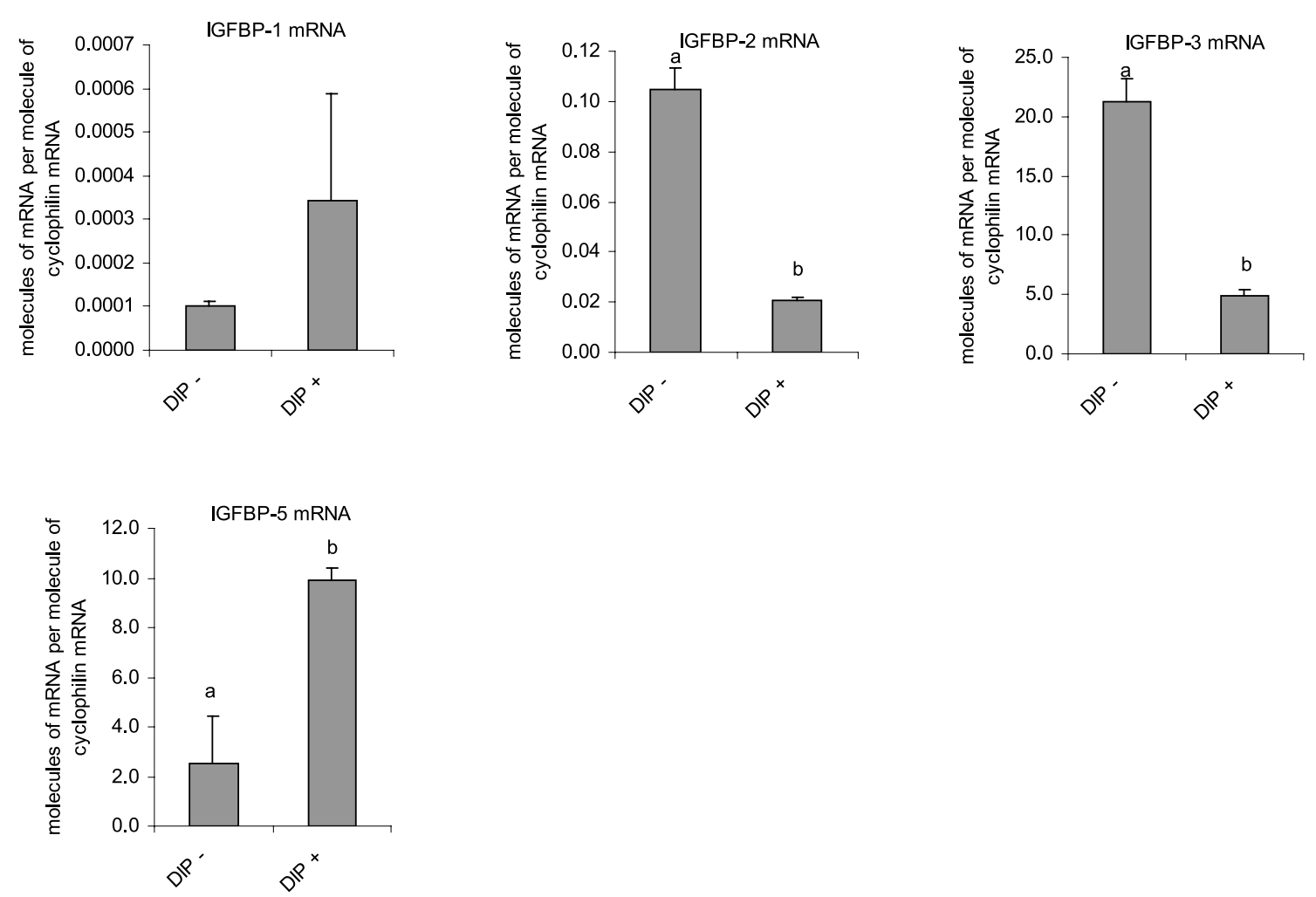

Figure 5 mRNA levels of IGFBP-1, $-2,-3$ and 5 in DIP-treated (DIP+) and -untreated (DIP-) HC11 cells $(n=6)$ (expressed in numbers of mRNA molecules per molecule of cyclophilin mRNA. Means with different superscript letters $(a$ and $b)$ differ significantly $(P<0.05)$. IGFBP-4 and -6 levels were undetectable.

Knight 2002). Intriguingly, however, we observed low levels of IGFR expression at L10 with an eightfold increase in IGFR expression on I2, implying that IGF-I may negatively regulate expression of its receptor. Two recent publications have shown that IGF-II expression is increased by prolactin in the mammary gland (Brisken et al. 2002, Hovey et al. 2003). Our results would support these findings since IGF-II expression increased threefold at lactogenesis when prolactin secretion increases dramatically. However, IGF-II concentrations subsequently fell despite the fact that prolactin levels remain elevated throughout lactation, suggesting that during galactopoiesis the stimulatory role of prolactin may be lost or antagonised.

Previous work from others predominantly localised IGFR and IGF-II to the epithelial cell population in the mouse mammary gland, whereas little IGF-I was detected there (Richert \& Wood 1999), and a second recent study demonstrated that the prolactin receptor and IGF-II are co-ordinately regulated in the mammary epithelium following knock-out of CCAAT enhancer binding protein $\beta$ (Grimm \& Rosen 2003). Furthermore, a third study located IGF-I exclusively in the stromal portion of the gland (Yee et al. 1989).

IGFBP-3 expression was high in the mammary gland although its synthesis appeared to be constitutive. Therefore, despite the fact that IGFBP-3 is the major binding protein in serum, it appears that in the mammary gland there is also the need for significant local production of IGFBP-3. Previous in situ hybridisation work from others has shown that IGFBP-3 transcripts localise to epithelial cells in the mouse mammary gland (Wood et al. 2000). In contrast to IGFBP-3, IGFBP-5 expression appeared to be highly regulated. In situ analyses have also localised IGFBP-5 transcripts to epithelial cells in mouse and rat mammary glands (Tonner et al. 1997, Wood et al. 2000, Rosato et al. 2002). In the mammary 
gland, the induction of IGFBP- 5 mRNA between L10 and I2 is extremely pronounced (54-fold) and reaches levels of expression at least an order of magnitude greater than any of the other IGFBPs (Fig. 3) in any of the other developmental stages. This corroborates our previous findings in the rat where the levels of IGFBP-5 protein were much higher during involution (Tonner et al. 1997), and demonstrates that this up-regulation of IGFBP-5 operates at either the level of transcriptional control or message stability. It is important to recognise that IGFBP-5 may induce cell death at the beginning of involution in a manner which is independent of its ability to bind to IGF-I. This is supported by recent work from others, where the ability of IGFBP-5 to inhibit the growth of human breast cancer cells both in vitro and in vivo was shown to be via an IGF-independent effect of the binding protein (Butt et al. 2003). The major increase in IGFBP-6 expression during the involutionary phase, which was similar, though not identical, to IGFBP-5, would tempt us to speculate that it may serve to sequester IGF-II during involution, to aid in the cell death programme. Support for this concept comes from the fact that IGFBP-6 has a much higher affinity for IGF-II than for IGF-I and that IGFBP-6 has been shown to be pro-apoptotic in other systems (Kuhl et al. 2003).

A second important correlate between the mRNA expression profile of an IGF and that of an IGFBP in the mammary gland is the similar spike of expression for both IGF-II and IGFBP-2 at L1. Interestingly, the mRNA expression patterns of IGF-II and IGFBP-2 have previously been shown to often overlap or be in adjacent tissues in developing mouse and rat embryos (Allan et al. 2001). In general, it appeared that their embryonic expression patterns were closely associated with regions of epithelial-mesenchymal cell interactions, where signals from one region have been shown to direct the growth and differentiation of neighbouring cells and tissues. From the embryonic studies, the clear implication is that IGFBP-2 is involved in the regulation of IGF-II action during these cellular interactions, and it may be that IGFBP-2 and IGF-II act in an analogous way during morphogenesis in the adult mammary gland.

HC11 cells have been used extensively as a model of mammary differentiation. Derived from mid-pregnant mouse mammary gland, they can be induced to differentiate sufficiently to express $\beta$-casein, a classical marker of mammary epithelial cells. However, it should be noted that they express $\beta$-casein at extremely low levels compared with normal mammary gland and they do not synthesise other caseins characteristically present in milk. Thus they probably represent the earliest stages of differentiation, possibly limited by their inability to secrete caseins to any great extent. Notwithstanding these limitations, they served as a useful comparison for the changes occurring between P18 and L1, which DIP treatment of HC11 cells attempts to mimic. Thus HC11 cells expressed very low levels of IGF-I and -II compared with normal mammary tissue, supporting the concept that the major site of their production is the stroma. HC11 cells did not express IGFBP-4 or -6 whilst both were expressed in mammary tissue, again suggesting the stroma as the main source. Both HC11 cells and mammary tissue expressed very low levels of IGFBP-1, indicating that this binding protein does not play a major role in the mammary gland at this time. Although IGFBP-2 was expressed at similar levels in HC11 and mammary tissue this IGFBP changed in opposite directions during DIP treatment of HC11 cells and differentiation of the mammary gland. HC11 cells also expressed IGFBP-3 and -5 at levels orders of magnitude greater than during differentiation of the mammary gland. These changes could not be explained in terms of dilution of IGFBP-3 or -5 message by stromal cells in the mammary gland since epithelial cells represent $70-90 \%$ of the cells at these time-points. Thus these results identify some similarities and differences in the expression of IGFBPs between HC11 cells and the normal mammary gland which are worthy of study, most notably the differential regulation of IGFBP-2 and the site of expression of IGFBP-4 and -6.

In conclusion, this is the first report of quantitative RT-PGR used to examine the IGF axis in the mammary gland and it has demonstrated the importance and complexity of this axis during gland development. We have described mRNA expression profiles that not only suggest differential roles for the various components of this axis throughout the mammary developmental stages, but also identified potential interactions and co-regulation between different members of this growth factor family. Our results have demonstrated the utility of this technique since it has confirmed and extended our previous functional 
studies aimed at addressing the significant changes which occur in IGFBP-5 expression during mammary involution. We believe that the data generated in this study will stimulate the formulation of testable hypotheses which will form the basis for future functional studies on the role of the IGF axis in tissue morphogenesis.

\section{Acknowledgements}

We thank M Gardner for skilled technical assistance. This work was supported by the Scottish Executive Environment and Rural Affairs Department. M B was supported by INRA, France.

\section{References}

Allan GJ, Flint DJ \& Patel K 2001 Insulin-like growth factor axis during embryonic development. Reproduction 122 31-39.

Allan GJ, Tonner E, Barber MC, Travers MT, Shand JH, Vernon RG, Kelly PA, Binart N \& Flint DJ 2002 Growth hormone, acting in part through the insulin-like growth factor axis, rescues developmental, but not metabolic, activity in the mammary gland of mice expressing a single allele of the prolactin receptor. Endocrinology 143 4310-4319.

Ball RK, Friis RR, Schoenenberger CA, Doppler W \& Groner B $1988 a$ Prolactin regulation of beta-casein gene expression and of a cytosolic 120 -kd protein in a cloned mouse mammary epithelial cell line. EMBO fournal 7 2089-2095.

Ball RK, Ziemiecki A, Schonenberger CA, Reichmann E, Redmond SM \& Groner B $1988 b$ v-myc alters the response of a cloned mouse mammary epithelial cell line to lactogenic hormones. Molecular Endocrinology 2 133-142.

Brisken C, Ayyannan A, Nguyen C, Heineman A, Reinhardt F, Tan J, Dey SK, Dotto GP, Weinberg RA \& Jan T 2002 IGF-2 is a mediator of prolactin-induced morphogenesis in the breast. Developmental Cell 3 877-887.

Butt AJ, Dickson KA, McDougall F \& Baxter RC 2003 Insulin-like growth factor-binding protein-5 inhibits the growth of human breast cancer cells in vitro and in vivo. Fournal of Biological Chemistry 278 29676-29685.

Fielder PJ, Thordarson G, English A, Rosenfeld RG \& Talamantes F 1992 Expression of a lactogen-dependent insulin-like growth factor-binding protein in cultured mouse mammary epithelial cells. Endocrinology 131 261-267.

Flint DJ, Tonner E \& Allan GJ 2000 Insulin-like growth factor binding proteins: IGF-dependent and -independent effects in the mammary gland. Fournal of Mammary Gland Biology and Neoplasia $\mathbf{5}$ 65-73.

Geier A, Haimshon M, Beery R, Hemi R \& Lunenfeld B 1992 Insulinlike growth factor-1 inhibits cell death induced by cycloheximide in MCF-7 cells: a model system for analyzing control of cell death. In Vitro Cellular and Developmental Biology 28 725-729.

Grimm SL \& Rosen JM 2003 The role of C/EBPbeta in mammary gland development and breast cancer. Fournal of Mammary Gland Biology and Neoplasia 8 191-204.

Hadsell DL, Greenberg NM, Fligger JM, Baumrucker CR \& Rosen JM 1996 Targeted expression of des(1-3) human insulin-like growth factor I in transgenic mice influences mammary gland development and IGF-binding protein expression. Endocrinology $137321-330$.

Hasel KW \& Sutcliffe JG 1990 Nucleotide sequence of a cDNA coding for mouse cyclophilin. Nucleic Acids Research 184019.

Hovey RC, Harris J, Hadsell DL, Lee AV, Ormandy CJ \& Vonderhaar BK 2003 Local insulin-like growth factor-II mediates prolactin-induced mammary gland development. Molecular Endocrinology 17 460-471.

Huynh H, Yang XF \& Pollak M 1996 A role for insulin-like growth factor binding protein 5 in the antiproliferative action of the antiestrogen ICI 182780. Cell Growth and Differentiation 7 1501-1506.

Hwa V, Oh Y \& Rosenfeld RG 1999 The insulin-like growth factor-binding protein (IGFBP) superfamily. Endocrinology Reviews 20 761-787.

Imagawa W, Spencer EM, Larson L \& Nandi S 1986 Somatomedin-C substitutes for insulin for the growth of mammary epithelial cells from normal virgin mice in serum-free collagen gel cell culture. Endocrinology 119 2695-2699.

Kuhl NM, Hoekstra D, De Vries H \& De Keyser J 2003 Insulin-like growth factor-binding protein 6 inhibits survival and differentiation of rat oligodendrocyte precursor cells. Glia $\mathbf{4 4}$ 91-101.

McGrath MF, Collier RJ, Clemmons DR, Busby WH, Sweeny CA \& Krivi GG 1991 The direct in vitro effect of insulin-like growth factors (IGFs) on normal bovine mammary cell proliferation and production of IGF binding proteins. Endocrinology 129 671-678.

Marshman E, Green KA, Flint DJ, White A, Streuli CH \& Westwood M 2003 Insulin-like growth factor binding protein 5 and apoptosis in mammary epithelial cells. Fournal of Cell Science 116 675-682.

Moorehead RA, Fata JE, Johnson MB \& Khokha R 2001 Inhibition of mammary epithelial apoptosis and sustained phosphorylation of Akt/PKB in MMTV-IGF-II transgenic mice. Cell Death and Differentiation 8 16-29.

Neuenschwander S, Schwartz A, Wood TL, Roberts CT Jr, Henninghausen L \& LeRoith D 1996 Involution of the lactating mammary gland is inhibited by the IGF system in a transgenic mouse model. Fournal of Clinical Investigation 97 2225-2232.

Oh Y, Muller HL, Lamson G \& Rosenfeld RG 1993 Insulin-like growth factor (IGF)-independent action of IGF-binding protein-3 in Hs578T human breast cancer cells. Cell surface binding and growth inhibition. Fournal of Biological Chemistry 268 14964-14971.

Phillips K, Park MA, Quarrie LH, Boutinaud M, Lochrie JD, Flint DJ, Allan GJ \& Beattie J 2003 Hormonal control of IGF-binding protein (IGFBP)-5 and IGFBP-2 secretion during differentiation of the HC11 mouse mammary epithelial cell line. Fournal of Molecular Endocrinology 31 197-208.

Purup S, Vestergaard M \& Sejrsen K 2000 Involvement of growth factors in the regulation of pubertal mammary growth in cattle. Advances in Experimental Medicine and Biology $4802-43$.

Rajah R, Valentinis B \& Cohen P 1997 Insulin-like growth factor (IGF)-binding protein-3 induces apoptosis and mediates the effects of transforming growth factor-betal on programmed cell death through a p53- and IGF-independent mechanism. Fournal of Biological Chemistry 272 12181-12188.

Richert MM \& Wood TL 1999 The insulin-like growth factors (IGF) and IGF type I receptor during postnatal growth of the murine mammary gland: sites of messenger ribonucleic acid expression and potential functions. Endocrinology $140454-461$.

Rosato R, Lindenbergh-Kortleve D, Neck J, Drop S \& Jahn G 2002 Effect of chronic thyroxine treatment on IGF-I, IGF-II and IGF-binding protein expression in mammary gland and liver during pregnancy and early lactation in rats. European fournal of Endocrinology 146 729-739.

Rozen F, Yang XF, Huynh H \& Pollak M 1997 Antiproliferative action of vitamin D-related compounds and insulin-like growth 
factor-binding protein 5 accumulation. Fournal of the National Cancer Institute 89 652-656.

Ruan W \& Kleinberg DL 1999 Insulin-like growth factor I is essential for terminal end bud formation and ductal morphogenesis during mammary development. Endocrinology 140 5075-5081.

Schuller AG, Groffen C, van Neck JW, Zwarthoff EG \& Drop SL 1994 cDNA cloning and mRNA expression of the six mouse insulin-like growth factor binding proteins. Molecular and Cellular Endocrinology 104 57-66.

Skaar TC \& Baumrucker CR 1993 Regulation of insulin-like growth factor binding protein secretion by a murine mammary epithelial cell line. Experimental Cell Research 209 183-188.

Sorensen A \& Knight CH 2002 Endocrine profiles of cows undergoing extended lactation in relation to the control of lactation persistency. Domestic Animal Endocrinology 23 111-123.

Strange KS, Wilkinson D \& Emerman JT 2002 Mitogenic properties of insulin-like growth factors I and II, insulin-like growth factor binding protein-3 and epidermal growth factor on human breast epithelial cells in primary culture. Breast Cancer Research and Treatment 75 203-212.

Stull MA, Richert MM, Loladze AV \& Wood TL 2002 Requirement for IGF-I in epidermal growth factor-mediated cell cycle progression of mammary epithelial cells. Endocrinology 143 1872-1879.

Tonner E, Quarrie L, Travers M, Barber M, Logan A, Wilde C \& Flint D 1995 Does an IGF-binding protein (IGFBP) present in involuting rat mammary gland regulate apoptosis? Progress in Growth Factor Research 6 409-414.

Tonner E, Barber MC, Travers MT, Logan A \& Flint DJ 1997 Hormonal control of insulin-like growth factor-binding protein-5 production in the involuting mammary gland of the rat. Endocrinology 138 5101-5107.

Tonner E, Allan G, Shkreta L, Webster J, Whitelaw CB \& Flint DJ 2000 Insulin-like growth factor binding protein-5 (IGFBP-5) potentially regulates programmed cell death and plasminogen activation in the mammary gland. Advances in Experimental Medicine and Biology 480 45-53.

Tonner E, Barber MC, Allan GJ, Beattie J, Webster J, Whitelaw CB \& Flint DJ 2002 Insulin-like growth factor binding protein-5 (IGFBP-5) induces premature cell death in the mammary glands of transgenic mice. Development 129 4547-4557.

Travers MT, Barber MC, Tonner E, Quarrie L, Wilde CJ \& Flint DJ 1996 The role of prolactin and growth hormone in the regulation of casein gene expression and mammary cell survival: relationships to milk synthesis and secretion. Endocrinology 137 1530-1539.

Wood TL, Richert MM, Stull MA \& Allar MA 2000 The insulin-like growth factors (IGFs) and IGF binding proteins in postnatal development of murine mammary glands. Fournal of Mammary Gland Biology and Neoplasia 5 31-42.

Yee D 1994 The insulin-like growth factor system as a target in breast cancer. Breast Cancer Research and Treatment 32 85-95.

Yee D, Paik S, Lebovic GS, Marcus RR, Favoni RE, Cullen KJ, Lippman ME \& Rosen N 1989 Analysis of insulin-like growth factor I gene expression in malignancy: evidence for a paracrine role in human breast cancer. Molecular Endocrinology 3 509-517.

Received 26 January 2004 Accepted 23 April 2004 